\title{
Editorial \\ Early Remarks From the Editorial Office
}

International Psychogeriatrics has moved. In January 1996, I took over as editor-in-chief and the editorial office moved to St. Louis University Medical School, where I am located. Fern Finkel will remain as managing editor in Chicago. Springer Publishing Company will continue to publish the journal from New York.

For those who are now thoroughly confused, a little history. Although the International Psychogeriatric Association (IPA) started out in the early 1980s, it was not until 1989 that International Psychogeriatrics was inaugurated. Since then, there have been about 12 semiannual issues, 4 quarterly issues, and several special supplements. Editorial responsibility has varied, with an editor-in-chief initially and a group of editors subsequently. It is to the credit of the editors, Gene Cohen, Sandy Finkel, Manfred Bergener, Kazuo Hasegawa, and Akira Homma, managing editor Fern Finkel, the staff at AMC (the consulting agency in Chicago), and of course, Springer, that the journal has been successful to date. The fiscal side has been overhauled, principally by George Grossberg. The association now owns and controls the journal.

This is all very exciting and challenging, and we intend to capitalize on two of the journal's major assets. First, the journal is truly international. Manuscripts are sent from, and read, all over the world. This reflects the 1,200 members of IPA, who represent all the continents. This cannot be emphasized too much and needs to be placed beside several important trends. First, there is a tendency for investigators of all languages to publish in English-language journals, and increasingly this means U.S. publications. Nevertheless, given all of that, there is parochialism with scientists, even English-speaking ones, preferring to read only their national journals. Obviously, International Psychogeriatrics must transcend this and become the major publication of its kind. We want to attract manuscripts from all over the world, particularly from those countries hitherto underrepresented. Although the English language will remain the official language of the journal, efforts will be made to keep our readers involved by having abstracts, and possibly articles, in other languages. If need be, we will develop mentoring systems for those unaccustomed to writing medical articles in internationally recognized English-language journals.

The second asset to highlight is that the journal is on Index Medicus. This is vitally important because it means that we will become known to and cited by other people in medicine. 
How are we going to operate? Ideally, we will have an editorial office "without walls." Although we assume that paper will be around for a time yet, we will rely heavily on electronic communication. Obviously, this cannot be done for all parts of the world; a Web site is still a luxury, but phones, faxes, and voice mail are everywhere. So we aim for a rapid turnaround and expect to have no difficulty in publishing quarterly. Initially, our circulation will be to the 1,200 members of IPA, and Springer's 200 individual and institutional readers, but as the organization expands and libraries increase subscriptions, these figures will increase. To foster local interest, and generate quality articles, there will be a small group of associate editors and a large group of corresponding editors from around the world. An advisory board will consist of members rotating on and off every few years. We welcome ethnic diversity and gender equality.

Traditionally, the journal has printed primarily research articles with a few house advertisements for IPA activities. This will change, with new features being invited: editorials, special features and issues (several supplements have already appeared), correspondence columns, and book reviews. We have ambitious plans for increased advertising and better artwork. Since the journal is now a quarterly, reflecting increased visibility, preference will be given to original articles; but equal emphasis will be given for the time being to reviews of special topics, which are a typical feature of quarterly journals. Both past and present editors have realized that a speedier review of manuscripts is essential and can be accomplished with better use of electronic aids, but more critically, with the good will and cooperation of colleagues and friends of the journal. Needless to say, considerable attention will be given to copyediting and proofreading since we expect that many of our authors will not have English as a first language.

There are several issues in preparation for 1996, so the suggested changes will not be immediate. They will gradually happen during 1996 and into 1997. As improvements occur, we will be happy to receive constructive comments. We hope that you will join us in celebrating the renewal and expanded growth of International Psychogeriatrics.

Robin Eastwood, MD

Editor-in-Chief

St. Louis, MO, U.S.A. 